\title{
White Blood Cell Count Predicts All-Cause Mortality in Patients Suspected of Having Peripheral Arterial Disease
}

\author{
Faisal A. Arain, MD, Mahyar Khaleghi, MD, Kent R. Bailey, PhD, Brian D. Lahr, MS, Thom W. \\ Rooke, MD, and Iftikhar J. Kullo, MD \\ From the Gonda Vascular Center and the Division of Cardiovascular Diseases (F.A.A, M.K, T.W.R, \\ I.J.K) and Division of Biomedical Statistics and Informatics (K.R.B, B.D.L), Mayo Clinic, Rochester, \\ Minnesota
}

\begin{abstract}
Background-We investigated whether markers of inflammation - white blood cell count, Creactive protein (CRP), and lipoprotein-associated phospholipase A2 (Lp-PLA2) - are associated with mortality in patients referred for non-invasive lower extremity arterial evaluation.

Methods and Results-Participants ( $\mathrm{n}=242$, mean age $68 \mathrm{y}, 54 \%$ men) were followed for a median of 71 months. Ankle-brachial index (ABI), WBC count, plasma CRP and Lp-PLA2 were measured at the start of the study. Factors associated with all-cause mortality were identified using Cox proportional hazards. During the follow-up period 56 (25\%) patients died. Factors associated with higher mortality were greater age, history of coronary artery disease/cerebrovascular disease, lower ABI, higher serum creatinine and higher white blood cell count/plasma CRP. In stepwise multivariable regression analysis, ABI, serum creatinine, white blood cell count and CRP were significantly associated with mortality. Patients in the top tertile of white blood cell count and CRP level had a relative risk of mortality of 3.37 (CI=1.56-7.27) and $2.12(\mathrm{CI}=0.97-4.62)$, respectively. Only the white blood cell count contributed to prediction of mortality. Inferences were similar when analyses were limited to patients with peripheral arterial disease (ABI $<0.9, \mathrm{n}=114)$.
\end{abstract}

Conclusion-White blood cell count, but not plasma CRP level, provides incremental information about the risk of death in patients referred for lower extremity arterial evaluation, and in the subset of these patients with peripheral arterial disease.

\section{Keywords}

Peripheral vascular disease; Pathophysiology; Risk Factors

\section{Introduction}

Peripheral arterial disease affects $\sim 8$ million people in the United States ${ }^{1}$ and is associated with three-fold higher risk of all-cause mortality and a six-fold higher risk of cardiovascular related mortality independent of conventional risk factors. ${ }^{2}$ Peripheral arterial disease is a surrogate of systemic atherosclerosis and is considered a coronary artery disease risk

(C) 2009 Elsevier Inc. All rights reserved.

Corresponding Author: Faisal A. Arain, M.D., Vascular Medicine Fellow, Division of Cardiovascular Disease, Mayo Clinic. 200 First Street SW, Rochester, MN 55905, Tel: (507) 284-3545; Fax: (507 266-1617, arain.faisal@mayo.edu.

Publisher's Disclaimer: This is a PDF file of an unedited manuscript that has been accepted for publication. As a service to our customers we are providing this early version of the manuscript. The manuscript will undergo copyediting, typesetting, and review of the resulting proof before it is published in its final citable form. Please note that during the production process errors may be discovered which could affect the content, and all legal disclaimers that apply to the journal pertain. 
equivalent. ${ }^{3,}{ }^{4}$ Inflammation is suspected of playing a central role in the development and progression of systemic atherosclerosis. ${ }^{5}$

Markers of inflammation including white blood cell (WBC) count, C-reactive protein (CRP) and lipoprotein-associated phospholipase A2 (Lp-PLA2) are associated with increased risk of myocardial infarction, peripheral arterial disease and stroke. ${ }^{5-8}$ There is also evidence that inflammatory markers are associated with higher mortality and adverse cardiovascular outcomes in patients with known atherosclerotic vascular disease. ${ }^{9-13}$ We hypothesized that in patients suspected to have peripheral arterial disease and referred for non-invasive lower extremity arterial evaluation, the white blood cell count, and plasma levels of CRP and LpPLA2 would be associated with mortality in the intermediate-term.

\section{Methods}

The study protocol was approved by the Institutional Review Board of the Mayo Clinic. Between October 2001 and March 2002, 756 patients were referred to the non-invasive vascular laboratory of the Gonda Vascular Center for lower extremity arterial evaluation. Patients who had poorly compressible vessels (ankle brachial index $(\mathrm{ABI})>1.3, \mathrm{n}=127$ ) were excluded. After completion of the arterial evaluation, a study assistant was able to approach approximately every other patient for participation in the study. From the 629 eligible patients, 242 patients consented to participate in the study. No significant differences in mean age and the proportion of women were noted between the eligible patients and those who consented to participate in this study. Medical records were reviewed to ascertain demographic information, anthropometric variables, plasma lipids, fasting glucose, serum creatinine and conventional cardiovascular risk factors such as diabetes mellitus, hypertension, hyperlipidemia, smoking status, renal failure, history of coronary artery disease (myocardial infarction, angina, abnormal stress test or coronary revascularization) or cerebrovascular disease (ischemic stroke or carotid revascularization). Use of medications that might affect the levels of inflammatory biomarkers (aspirin and statins) was also recorded. ABI was measured in the non-invasive vascular laboratory using an established protocol. ${ }^{14}$ The white blood cell count and plasma CRP and Lp-PLA2 levels were measured in blood samples obtained by venipuncture after an overnight fast as described in our earlier study. ${ }^{15}$

Patients were followed until December 31, 2007. Of the 242 patients enrolled in the study, follow-up information was available on 226 patients (93\%). The Mayo Clinic electronic medical record was reviewed for details for every inpatient hospitalization, outpatient visit, all laboratory and pathology results, notification of death and relevant correspondence and phone calls with the patients or the referring physicians. Patients who had not been seen at the Mayo Clinic nor had any correspondence with the Mayo Clinic for more than 1 year were contacted by telephone and interviewed by one of the investigators (FAA). Vital status was ascertained by review of medical records, phone interview of the family members of the deceased patients and by utilizing the Accurint ${ }^{\circledR}$ database (a research tool to verify patient address, phone number and vital status). ${ }^{16}$

\section{Statistical analysis}

Continuous variables were reported as mean $\pm \mathrm{SD}$ (as well as median and quartiles) and categorical variables as percentages for all participants, survivors, and decedents. We used Spearman correlation coefficients to assess the correlations between white blood cell count, CRP and Lp-PLA2. To evaluate the association of white blood cell count, CRP and Lp-PLA2 with all-cause mortality, we categorized the participants according to tertiles of white blood cell count, CRP and Lp-PLA2, with participants in lowest tertiles considered the referent group. Survival was estimated by Kaplan-Meier method. The association of baseline characteristics (age, sex, body mass index, diabetes, smoking, hypertension, total cholesterol, HDL 
cholesterol, previous history of coronary artery disease/cerebrovascular disease, statin use, aspirin use and $\mathrm{ABI}$ ) with mortality was assessed using univariate Cox proportional hazards (Cox PH) models. We used multivariable Cox PH models to assess whether white blood cell count, CRP and Lp-PLA2 each were independently associated with mortality, after adjustments for: a) age and sex; b) age, sex and variables significant in the univariate Cox PH models; and c) the previous variables plus resting $\mathrm{ABI}$.

The discriminative ability (i.e., ability to distinguish subjects who died from those who survived) of various Cox PH models was evaluated using a concordance statistic, the $c$ statistic (equivalent to the area under the receiver-operating characteristic curve). In addition, the discriminative value of each inflammatory biomarker beyond known risk factors was compared using the Integrated Discrimination Improvement (IDI) statistic as proposed by Pencina et al. ${ }^{17} 18$ IDI is the difference in discriminative ability between two models according to their predicted survival probabilities. Comparing one model to another, an increased probability of death among subjects who died and a decreased probability of death among subjects who survived implies better predictive ability, whereas the opposite implies worse predictive ability. These two changes are summed (improvement always considered positive), and the standard error is calculated based on the sum of squares of the standard errors for each mean change. A two-sided $P$-value of $<0.05$ was deemed statistically significant. Statistical analyses were carried out using SAS v 8.2 (SAS Institute, Cary NC) software package.

\section{Results}

\section{Patient Characteristics}

Follow-up (median 71 months) was available on $93 \%$ of the participants ( $\mathrm{n}=226)$. The mean age of these patients was $68.4 \pm 11$ years and $54 \%$ (121) were men. Diabetes was present in 25 $\%(\mathrm{n}=56)$, hypertension in $66 \%(\mathrm{n}=150)$, hyperlipidemia in $47 \%(\mathrm{n}=105)$ and tobacco use in $61 \%(\mathrm{n}=137)$ of participants. At the time of enrollment, $54 \%(\mathrm{n}=122)$ of participants had coronary artery or cerebrovascular disease and $50 \%(\mathrm{n}=114)$ had peripheral arterial disease based on a resting ABI $<0.9$. During the follow-up period 56 patients $(25 \%)$ died (Table 1$)$. Patients who died were older, had a higher prevalence of coronary artery disease/ cerebrovascular disease and peripheral arterial disease and had higher serum creatinine, white blood cell count and CRP level than those presumed alive on December 31, 2007. Rates of statin and antiplatelet use and levels of total cholesterol, HDL cholesterol and Lp-PLA2 did not differ between survivors and decedents (Table 1). Spearman correlation coefficients for the inflammatory markers were: WBC-CRP $(0.22, P=0.001)$, CRP-Lp-PLA2 $(0.03, P=0.65)$ and WBC-Lp-PLA2 (0.11, $P=0.13)$.

\section{Predictors of Mortality}

Kaplan-Meier survival curves show that over 71 months of follow-up, patients in the top tertiles of white blood cell count and CRP had lower rates of survival than those in the bottom tertiles (Figure 1).

In univariate Cox $\mathrm{PH}$ models, age, history of coronary artery disease/cerebrovascular disease, ABI $<0.9$, serum creatinine, white blood cell count (top versus bottom tertile) and CRP (top versus bottom tertile) were associated with higher risk of mortality (Table 2). The associations of white blood cell count, CRP and Lp-PLA2 with mortality were further analyzed using multivariable Cox PH models (Table 3). After adjustment for age and sex, patients in the top tertile of white blood cell count $\left(\geq 7.9 \times 10^{3} / \mathrm{mm}^{3}\right)$ had a higher risk of death than those in the bottom tertile $\left(<6.3 \times 10^{3} / \mathrm{mm}^{3}\right)$. This association remained significant after additional adjustment for smoking status, hypertension, history of coronary artery disease/ cerebrovascular disease, serum creatinine level and ABI (Table 3). CRP was also associated 
with mortality after adjustment for age and sex $(\mathrm{HR}=2.46,95 \% \mathrm{CI}=1.14-5.32)$ and marginally associated after additional adjustment for smoking status, hypertension, history of coronary artery disease/cerebrovascular disease, serum creatinine level and ABI (Table 3). Lp-PLA2 was not associated with all-cause mortality in unadjusted or adjusted models (Table 3). When white blood cell count and CRP level were included in the fully adjusted model, white blood cell count $(\mathrm{HR}=3.18,1.44-6.96)$ but not $\mathrm{CRP}(\mathrm{HR}=1.41(0.61-3.24)$, remained significantly associated with mortality.

In similar analyses of the subset of patients with PAD (ABI $<0.90, n=114$ ) (Table 3), the top tertile of white blood cell count and CRP level was associated with higher relative risk of death compared with the bottom tertile (HR=4.09, 1.57-10.64 and 2.70, 1.11-6.60 respectively). LpPLA2 was not associated with mortality in the subset of patients with PAD. When both white blood cell count and CRP level were included in the fully adjusted model, white blood cell count $(\mathrm{RR}=3.72,1.38-10.01)$ but not $\mathrm{CRP}(\mathrm{RR}=1.61,0.61-4.24)$ remained significantly associated with mortality. In the subset of participants without PAD, only 13 deaths occurred during the follow-up and the inflammatory markers were not significantly associated with mortality.

\section{Incremental Predictive Value of Markers of Inflammation}

Addition of white blood cell count or CRP to the base model (adjusted for age, sex, serum creatinine and $\mathrm{ABI}$ ) resulted in an increase in the $c$ statistic for prediction of mortality from 0.72 to 0.74 for white blood cell count, 0.73 for CRP level and 0.75 when both white blood cell count and CRP level were added. Similarly, in the subset of patients with peripheral arterial disease, there was an increase in the $c$ statistic from the base model (0.62) upon addition of white blood cell count (0.67) or CRP level (0.66). The increased discriminative value of the biomarkers was further examined with the "Integrated discrimination improvement" (IDI) method (Table 4). Addition of white blood cell count, but not CRP, to partially/fully adjusted models, resulted in an increase in IDI in both the entire sample and in the subset of patients with peripheral arterial disease (Table 4). The IDI of models with white blood cell was significantly greater than models with CRP (Table 4).

\section{Discussion}

The main findings of our study are: 1) Higher white blood cell count was associated with higher mortality in patients referred for non-invasive lower extremity arterial evaluation and in the subset of these patients with peripheral arterial disease; 2) White blood cell count but not CRP, provided prognostic information incremental to known risk markers including ABI; 3) Of the three inflammatory markers, white blood cell count provided the greatest incremental information about the risk of mortality and was associated with mortality independent of CRP.

We have previously noted a cross sectional association between plasma CRP and peripheral arterial disease in a biethnic cohort. ${ }^{19}$ In the National Health and Nutrition Examination Survey (1999-2002), a white blood cell count in the top quartile $\left(>7.3 \times 10^{3} / \mathrm{mm}^{3}\right)$ was associated with an odds ratio of 1.67 for peripheral arterial disease $(\mathrm{ABI}<0.9)$ compared to the bottom quartile $\left(\leq 4.9 \times 10^{3} / \mathrm{mm}^{3}\right) .{ }^{7}$ A subsequent analysis of the NHANES database found that monocytes were the only white blood cell subtype significantly and independently associated with peripheral arterial disease. ${ }^{20}$

Although, a number of studies have investigated the association of inflammatory markers with cardiovascular outcomes and mortality in patients with known atherosclerotic vascular disease, $10,13,21$ our study is the first to demonstrate that the white blood cell count is a significant predictor of death in patients referred for non-invasive lower extremity arterial evaluation, including the subset of these patients with peripheral arterial disease. Grau et $\mathrm{al}^{11}$ in a study 
of more than 18000 patients with known atherosclerotic vascular disease (history of stroke, MI or symptomatic peripheral arterial disease) found that white blood cell count $>8.2 \times 10^{3}$ /

$\mathrm{mm}^{3}$ (top quartile) was associated with higher risk of vascular death $(\mathrm{RR}=1.51)$ when compared to white blood cell count $\leq 5.85 \times 10^{3} / \mathrm{mm}^{3}$ (bottom quartile). The association of white blood cell count with all-cause mortality was not reported. Haumer et al ${ }^{12}$ followed 398 patients with symptomatic peripheral arterial disease (requiring revascularization or limb salvage for critical limb ischemia) for a median of 20 months. Compared to patients with neutrophil count $<4.4$ $\left(\times 10^{3} / \mathrm{mm}^{3}\right)$ (bottom tertile), those with neutrophil count $>5.8\left(\times 10^{3} / \mathrm{mm}^{3}\right)$ (highest tertile) were at a higher risk of major adverse cardiovascular events (myocardial infarction, need for percutaneous intervention, coronary bypass, stroke, carotid revascularization) $(\mathrm{HR}=1.8)$ and death $(\mathrm{HR}=3.4)$ and the composite end point of myocardial infarction, stroke and death $(\mathrm{HR}=2.2)$. Our results extend these findings to patients referred for lower extremity arterial evaluation and in the subset of these patients with peripheral arterial disease. Furthermore, by using the IDI, we demonstrate that white blood cell count provides incremental prediction of death. Finally, we demonstrate that white blood cell is a stronger predictor of mortality than plasma CRP.

Although white blood cell count could simply be a marker of inflammation in the setting of atherosclerotic vascular disease, it is possible that white blood cell may have a pathogenic role. The fact that white blood cell count was associated with mortality independent of plasma CRP supports this hypothesis. White blood cells may activate various cascades favoring plaque progression and rupture leading to acute coronary (or other ischemic) syndromes. ${ }^{5}, 22$ The possible mechanisms by which elevated white blood cell count may be related to adverse outcomes have been reviewed by Madjid et $\mathrm{al}^{23}$ and $\mathrm{Coller}^{22}$ and include increased inflammation, endothelial damage, procoagulant effects and microvascular damage. Indeed, Coller has proposed a clinical trial using agents that reduce white blood cell count, such as hydroxyurea, in patients with atherosclerotic vascular disease and increased risk of death. ${ }^{22}$

Plasma CRP is a non-specific circulating marker of inflammation ${ }^{24}$ that may have proatherogenic properties ${ }^{5,21,25}$ A plasma CRP level $>9 \mathrm{mg} / \mathrm{L}$ was associated with increased risk of fatal MI within two years after lower extremity revascularization (odds ratio=3.2 (1.0410). ${ }^{9}$ Beckman et $\mathrm{al}^{26}$ showed that in patients with peripheral arterial disease, the combination of CRP level (assessing severity of inflammation) and ABI (assessing magnitude of atherosclerosis) was a stronger predictor of adverse cardiovascular outcomes (myocardial infarction, stroke and death) than either one of these alone. In a prospective cohort study of patients with PAD identified from non-invasive vascular laboratories $(n=377)$, followed for a mean of 3.4 years ${ }^{13}$, higher baseline levels of CRP, serum amyloid A and D-dimer were associated with higher all-cause mortality. CRP and serum amyloid A level were each associated with higher all-cause mortality and cardiovascular mortality within 1 year and 1-2 years but not 2-3 years after measurement, whereas higher D-dimer level was significantly associated with mortality throughout the study period. The authors speculated that elevated levels of CRP and serum amyloid A, being more closely associated with near-term than laterterm all-cause mortality, may be markers of plaque instability. In contrast, we found that CRP was marginally associated with all cause mortality over a longer follow-up period (71 months).

Plasma Lp-PLA2 is an enzyme that circulates in blood mainly bound to low-density lipoprotein and has been proposed to have both proatherogenic/proinflammatory and antiatherogenic/antiinflammatory effects in the circulatory system. ${ }^{8}$ Our results are similar to those of Allison et $\mathrm{al}^{27}$ who investigated the association between Lp-PLA2 mass and total mortality in 508 patients seen in the non-invasive vascular laboratory for arterial evaluation and followed up for a mean of 6.7 years. They found no significant association between Lp-PLA2 mass and total cardiovascular mortality after adjustment for conventional risk factors and plasma lipid levels. 
We can not rule out the possibility that Lp-PLA2 activity and not mass, may be more informative in this setting.

The results of the present study indicate that the white blood cell count contributes incrementally to risk prediction, as assessed by the IDI. Although the $c$ statistic also improved with the inflammatory markers, the confidence intervals overlapped (analyses not shown), likely due to the relatively small number of deaths $(\mathrm{n}=56)$. Assessment of systemic inflammation, in addition to measurement of ABI may provide incremental prognostic information in patients referred to the vascular laboratory and in the subset of these patients with peripheral arterial disease. White blood cell count was the most powerful predictor of the three inflammatory markers and yielded the highest increment in IDI in the overall sample as well as in the subset of PAD patients.

Furthermore, white blood cell count remained an independent predictor of mortality even after adjustment for CRP. Thus white blood cell count, an inexpensive, readily available test, is a biomarker of mortality risk in patients suspected of having peripheral arterial disease.

Clinicians can use this biomarker to improve risk prognostication and identify patients who need aggressive treatment and close follow up.

\section{Study strengths and limitations}

Our study enrolled patients referred to the vascular laboratory of a tertiary medical center for non-invasive arterial evaluation and the results maybe generalizable to such a population. Our findings need to be confirmed in larger samples as well as in patients with peripheral arterial disease identified from the community. We were able to compare the relative predictive value of the white blood cell count with two clinical markers of inflammation - CRP and Lp-PLA2 - used in the clinical setting. Although hazard ratios and $P$-values are useful in determining statistical significance, these are not sufficient to establish incremental clinical utility of a biomarker. ${ }^{28}$ Using the IDI statistic, we demonstrated that white blood cell count improve risk prediction over and above established risk factors including ABI. Our inferences are limited to all-cause mortality as data for cause-specific mortality were not available. We used a single baseline measurement of each inflammatory marker and multiple measurements may have been more informative. Measurement of more "proximate" inflammatory markers such as cytokines may have yielded additional insights.

\section{Conclusion}

In patients who are referred for non-invasive lower extremity arterial evaluation, factors independently associated with mortality were; greater age, history of coronary artery disease/ cerebrovascular disease, presence of peripheral arterial disease, higher serum creatinine and elevated markers of systemic inflammation (white blood cell count and plasma CRP). Patients with white blood cell count $\geq 7.9\left(\times 10^{3} / \mathrm{mm}^{3}\right)$ and CRP level $\geq 5.5 \mathrm{mg} / \mathrm{L}$ have 3.1 and 2.3 times higher risk of death than those with levels $<6.3\left(\times 10^{3} / \mathrm{mm}^{3}\right)$ and $2.4 \mathrm{mg} / \mathrm{L}$, respectively. These findings suggest that that low-grade systemic inflammation is associated with higher intermediate-term mortality in such patients. Our findings are applicable to patients who are referred to the non-invasive vascular laboratory including those subsequently confirmed to have peripheral arterial disease. Further investigation is needed to identify potential drivers of inflammation in such a setting and to assess whether reducing systemic inflammation by pharmacologic and lifestyle intervention improves outcome.

\section{Clinical Significance}

- In patients with peripheral arterial disease (PAD), systemic inflammation may contribute to an increased risk of death. 
- WBC count, but not plasma CRP level, provides incremental information about the risk of death in patients referred for lower extremity arterial evaluation, and in the subset of patients with PAD.

- WBC count, an inexpensive, readily available test, is a biomarker of risk of death in patients suspected of having PAD.

\section{Acknowledgments}

Funding Source: Supported by NIH grants HL75794 and HL81331. Dr. Arain is supported by the NIH Vascular Medicine Training Program K12 grant (HL 083797).

\section{References}

1. Rosamond W, Flegal K, Friday G, Furie K, Go A, Greenlund K, Haase N, Ho M, Howard V, Kissela B, Kittner S, Lloyd-Jones D, McDermott M, Meigs J, Moy C, Nichol G, O'Donnell CJ, Roger V, Rumsfeld J, Sorlie P, Steinberger J, Thom T, Wasserthiel-Smoller S, Hong Y. Heart disease and stroke statistics--2007 update: a report from the American Heart Association Statistics Committee and Stroke Statistics Subcommittee. Circulation 2007;115(5):e69-e171. [PubMed: 17194875]

2. Criqui MH, Langer RD, Fronek A, Feigelson HS, Klauber MR, McCann TJ, Browner D. Mortality over a period of 10 years in patients with peripheral arterial disease. New England Journal of Medicine 1992;326(6):381-386. [PubMed: 1729621]

3. Steg PG, Bhatt DL, Wilson PWF, D'Agostino R Sr, Ohman EM, Rother J, Liau C-S, Hirsch AT, Mas J-L, Ikeda Y, Pencina MJ, Goto S, Investigators RR. One-year cardiovascular event rates in outpatients with atherothrombosis.[see comment]. JAMA 2007;297(11):1197-1206. [PubMed: 17374814]

4. Grundy SM, Cleeman JI, Merz CNB, Brewer HB Jr, Clark LT, Hunninghake DB, Pasternak RC, Smith SC Jr, Stone NJ. National Heart LaBI, American College of Cardiology F, American Heart A. Implications of recent clinical trials for the National Cholesterol Education Program Adult Treatment Panel III guidelines.[erratum appears in Circulation. 2004 Aug 10;110(6):763]. Circulation 2004;110 (2):227-239. [PubMed: 15249516]

5. Libby P. Inflammation in atherosclerosis. Nature 2002;420(6917):868-874. [PubMed: 12490960]

6. Ridker PM, Stampfer MJ, Rifai N. Novel risk factors for systemic atherosclerosis: a comparison of Creactive protein, fibrinogen, homocysteine, lipoprotein(a), and standard cholesterol screening as predictors of peripheral arterial disease.[see comment]. JAMA 2001;285(19):2481-2485. [PubMed: 11368701]

7. Wildman RP, Muntner P, Chen J, Sutton-Tyrrell K, He J. Relation of inflammation to peripheral arterial disease in the national health and nutrition examination survey, 1999-2002. American Journal of Cardiology 2005;96(11):1579-1583. [PubMed: 16310445]

8. Garza CA, Montori VM, McConnell JP, Somers VK, Kullo IJ, Lopez-Jimenez F. Association between lipoprotein-associated phospholipase A2 and cardiovascular disease: a systematic review.[see comment]. Mayo Clin Proc 2007;82(2):159-165. [PubMed: 17290721]

9. Rossi E, Biasucci LM, Citterio F, Pelliccioni S, Monaco C, Ginnetti F, Angiolillo DJ, Grieco G, Liuzzo G, Maseri A. Risk of myocardial infarction and angina in patients with severe peripheral vascular disease: predictive role of C-reactive protein. Circulation 2002;105(7):800-803. [PubMed: 11854118]

10. Haim M, Boyko V, Goldbourt U, Battler A, Behar S. Predictive value of elevated white blood cell count in patients with preexisting coronary heart disease: the Bezafibrate Infarction Prevention Study. Archives of Internal Medicine 2004;164(4):433-439. [PubMed: 14980995]

11. Grau AJ, Boddy AW, Dukovic DA, Buggle F, Lichy C, Brandt T, Hacke W. for the CI. Leukocyte Count as an Independent Predictor of Recurrent Ischemic Events. Stroke 2004;35(5):1147-1152. [PubMed: 15017013]

12. Haumer M, Amighi J, Exner M, Mlekusch W, Sabeti S, Schlager O, Schwarzinger I, Wagner O, Minar E, Schillinger M. Association of neutrophils and future cardiovascular events in patients with peripheral artery disease. Journal of Vascular Surgery 2005;41(4):610-617. [PubMed: 15874924] 
13. Vidula H, Tian L, Liu K, Criqui MH, Ferrucci L, Pearce WH, Greenland P, Green D, Tan J, Garside DB, Guralnik J, Ridker PM, Rifai N, McDermott MM. Biomarkers of inflammation and thrombosis as predictors of near-term mortality in patients with peripheral arterial disease: a cohort study. Annals of Internal Medicine 2008;148(2):85-93. [PubMed: 18195333]

14. Hirsch AT, Criqui MH, Treat-Jacobson D, Regensteiner JG, Creager MA, Olin JW, Krook SH, Hunninghake DB, Comerota AJ, Walsh ME, McDermott MM, Hiatt WR. Peripheral arterial disease detection, awareness, and treatment in primary care.[see comment]. JAMA 2001;286(11):13171324. [PubMed: 11560536]

15. Santos S, Rooke TW, Bailey KR, McConnell JP, Kullo IJ. Relation of markers of inflammation (Creactive protein, white blood cell count, and lipoprotein-associated phospholipase A2) to the anklebrachial index. Vascular Medicine 2004;9(3):171-176. [PubMed: 15675180]

16. Owan TE, Hodge DO, Herges RM, Jacobsen SJ, Roger VL, Redfield MM. Trends in Prevalence and Outcome of Heart Failure with Preserved Ejection Fraction. N Engl J Med 2006;355(3):251-259. [PubMed: 16855265]

17. Pencina MJ, D'Agostino RB Sr, D'Agostino RB Jr, Vasan RS. Evaluating the added predictive ability of a new marker: from area under the ROC curve to reclassification and beyond.[see comment]. Stat Med 2008;27(2):157-172. [PubMed: 17569110]discussion 207-112

18. Kim WR, Biggins SW, Kremers WK, Wiesner RH, Kamath PS, Benson JT, Edwards E, Therneau TM. Hyponatremia and Mortality among Patients on the Liver-Transplant Waiting List. N Engl J Med 2008;359(10):1018-1026. [PubMed: 18768945]

19. Khawaja FJ, Bailey KR, Turner ST, Kardia SL, Mosley TH Jr, Kullo IJ. Association of novel risk factors with the ankle brachial index in African American and non-Hispanic white populations. Mayo Clin Proc 2007;82(6):709-716. [PubMed: 17550751]

20. Nasir K, Guallar E, Navas-Acien A, Criqui MH, Lima JAC. Relationship of monocyte count and peripheral arterial disease: results from the National Health and Nutrition Examination Survey 19992002. Arterioscler Thromb Vasc Biol 2005;25(9):1966-1971. [PubMed: 15976323]

21. Vainas T, Stassen FRM, de Graaf R, Twiss ELL, Herngreen SB, Welten RJTJ, van den Akker LHJM, van Dieijen-Visser MP, Bruggeman CA, Kitslaar PJEHM. C-reactive protein in peripheral arterial disease: relation to severity of the disease and to future cardiovascular events. Journal of Vascular Surgery 2005;42(2):243-251. [PubMed: 16102622]

22. Coller BS. Leukocytosis and Ischemic Vascular Disease Morbidity and Mortality: Is It Time to Intervene? Arterioscler. Thromb. Vasc. Biol 2005;25(4):658-670. [PubMed: 15662026]

23. Madjid M, Awan I, Willerson JT, Casscells SW. Leukocyte count and coronary heart disease: Implications for risk assessment. J Am Coll Cardiol 2004;44(10):1945-1956. [PubMed: 15542275]

24. Wilson AM, Ryan MC, Boyle AJ. The novel role of C-reactive protein in cardiovascular disease: risk marker or pathogen. Int J Cardiol 2006;106(3):291-297. [PubMed: 16337036]

25. Libby P, Ridker PM, Maseri A. Inflammation and atherosclerosis.[see comment]. Circulation 2002;105(9):1135-1143. [PubMed: 11877368]

26. Beckman JA, Preis O, Ridker PM, Gerhard-Herman M. Comparison of usefulness of inflammatory markers in patients with versus without peripheral arterial disease in predicting adverse cardiovascular outcomes (myocardial infarction, stroke, and death). American Journal of Cardiology 2005;96(10):1374-1378. [PubMed: 16275181]

27. Allison MA, Denenberg JO, Nelson JJ, Natarajan L, Criqui MH. The association between lipoproteinassociated phospholipase A2 and cardiovascular disease and total mortality in vascular medicine patients. Journal of Vascular Surgery 2007;46(3):500-506. [PubMed: 17681710]

28. Greenland P, O'Malley PG. When is a new prediction marker useful? A consideration of lipoproteinassociated phospholipase A2 and C-reactive protein for stroke risk.[comment]. Archives of Internal Medicine 2005;165(21):2454-2456. [PubMed: 16314539] 

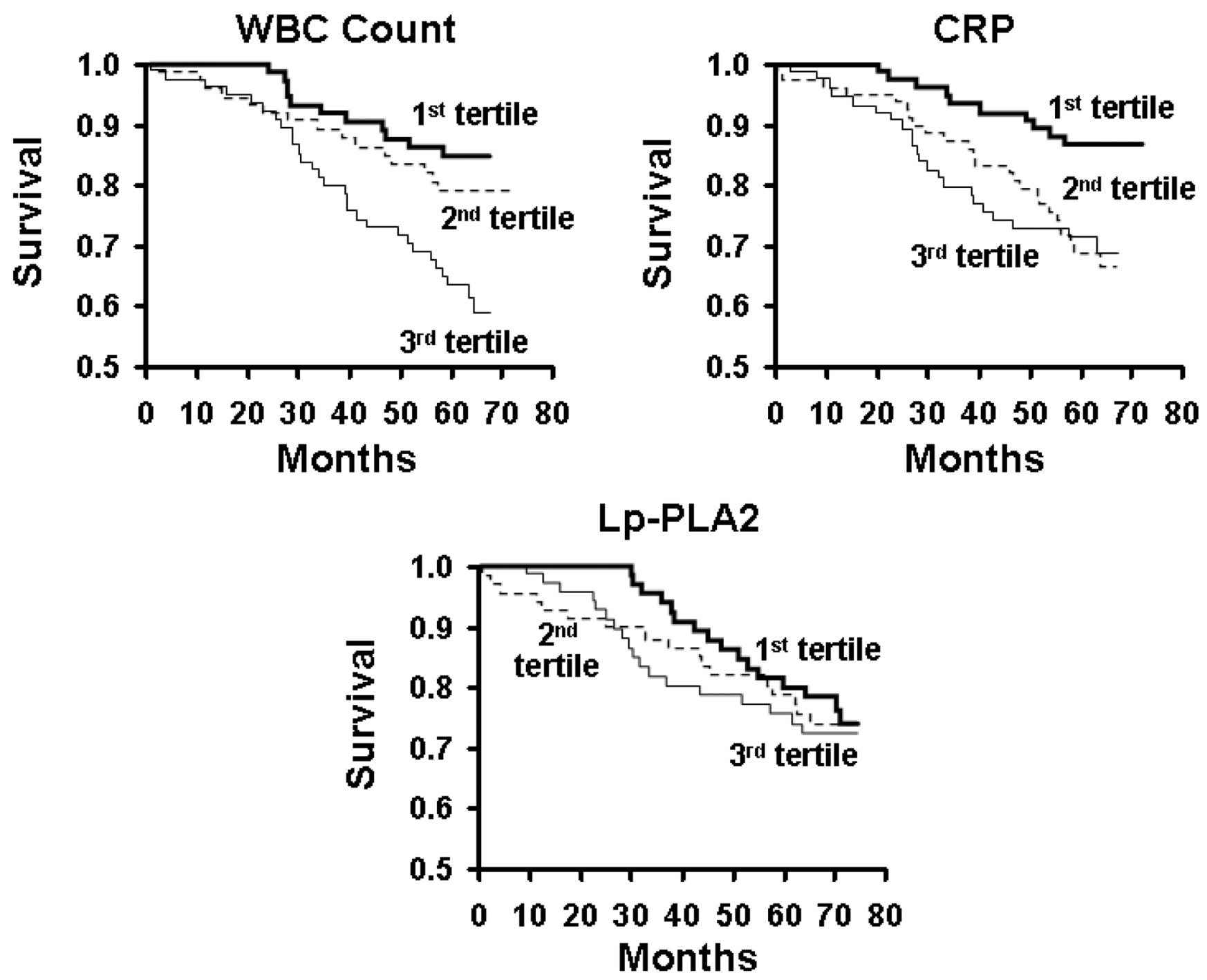

Figure 1.

Kaplan-Meier survival curves based on tertiles of WBC count and plasma levels of CRP and Lp-PLA2 
Table 1

Patient characteristics

\begin{tabular}{|c|c|c|c|}
\hline & $\begin{array}{l}\text { Alive at follow up } \\
n=170(\%)\end{array}$ & $\begin{array}{c}\text { Deceased at follow up } \\
n=56(\%)\end{array}$ & $P$-value \\
\hline Mean age (years) & $67.0 \pm 11.0$ & $72.6 \pm 9.8$ & $<0.01$ \\
\hline $\operatorname{Men}(\%)$ & $93(55 \%)$ & $28(50 \%)$ & 0.64 \\
\hline $\mathrm{BMI}\left(\mathrm{kg} / \mathrm{m}^{2}\right)$ & $28.3 \pm 4.8$ & $28.0 \pm 5.0$ & 0.63 \\
\hline Type II diabetes & $39(23 \%)$ & $17(30 \%)$ & 0.29 \\
\hline Smoking* & $98(58 \%)$ & $39(70 \%)$ & 0.12 \\
\hline Hypertension & $107(63 \%)$ & $43(77 \%)$ & 0.07 \\
\hline Total cholesterol (mg/dL) & $197.8 \pm 45.9$ & $195.7 \pm 45.7$ & 0.70 \\
\hline HDL cholesterol (mg/dL) & $50.2 \pm 16.9$ & $46.9 \pm 12.2$ & 0.34 \\
\hline History of CAD/ CVD & $84(49 \%)$ & $38(68 \%)$ & 0.02 \\
\hline Statin use & $79(47 \%)$ & $26(46 \%)$ & 1.00 \\
\hline Antiplatelet use & $81(48 \%)$ & $30(54 \%)$ & 0.54 \\
\hline Serum creatinine $(\mathrm{mg} / \mathrm{dL})$ & $1.18 \pm 0.34$ & $1.39 \pm 0.51$ & 0.02 \\
\hline $\operatorname{PAD}(\mathrm{ABI}<0.9)$ & $71(42 \%)$ & $43(77 \%)$ & $<0.01$ \\
\hline WBC count $\left(\times 10^{3} / \mathrm{mm}^{3}\right)$ & $7.0 \pm 2.1$ & $8.2 \pm 2.4$ & $<0.01$ \\
\hline $\mathrm{CRP}(\mathrm{mg} / \mathrm{L})$ & $5.1 \pm 6.8$ & $6.9 \pm 7.7$ & 0.01 \\
\hline Lp-PLA2 $(\mathrm{ng} / \mathrm{ml}) \dagger$ & $345.1 \pm 134.8$ & $344.6 \pm 141.4$ & 0.96 \\
\hline
\end{tabular}

Continuous variables are presented as mean $\pm \mathrm{SD}$; categorical variables are presented as percentages $(\%)$. $\mathrm{BMI}=$ body mass index; $\mathrm{HDL}=$ high-density lipoprotein, $\mathrm{CAD}=$ coronary artery disease, $\mathrm{CVD}=$ cerebrovascular disease, $\mathrm{PAD}=$ peripheral arterial disease, $\mathrm{ABI}=$ ankle-brachial index, $\mathrm{WBC}=$ white blood cell, CRP= C-reactive protein, Lp-PLA2= lipoprotein-associated phospholipase A2. 
Table 2

Univariate associations of risk factors with all-cause mortality

\begin{tabular}{lcc}
\hline & Hazard Ratio & Confidence Interval \\
\hline Age, $(10$ years) & 1.62 & $1.22-2.19$ \\
Male sex & 0.87 & $0.52-1.48$ \\
BMI $\left(\mathrm{kg} / \mathrm{m}^{2}\right)$ & 0.98 & $0.93-1.04$ \\
Type II diabetes & 1.35 & $0.77-2.39$ \\
Smoking (current or former) & 1.66 & $0.94-2.93$ \\
Hypertension & 1.82 & $0.98-3.38$ \\
Total cholesterol $(\mathrm{mg} / \mathrm{dL})$ & 1.00 & $0.99-1.00$ \\
Log HDL cholesterol $(\mathrm{mg} / \mathrm{dL})$ & 0.63 & $0.26-1.53$ \\
CAD/CVD & 1.95 & $1.11-3.42$ \\
Statin use & 0.98 & $0.58-1.65$ \\
Drug use & 1.21 & $0.71-2.04$ \\
Log serum creatinine $(\mathrm{mg} / \mathrm{dL})$ & 3.91 & $1.70-9.00$ \\
PAD $(\mathrm{ABI}<0.9)$ & 3.93 & $2.11-7.31$ \\
WBC count $\left(\times 10^{3} / \mathrm{mm}^{3}\right)^{*}$ & 3.22 & $1.57-6.62$ \\
CRP $(\mathrm{mg} / \mathrm{L})^{*}$ & 2.57 & $1.21-5.46$ \\
Lp-PLA2 $(\mathrm{ng} / \mathrm{ml})$ & 1.14 & $0.58-2.25$ \\
\end{tabular}

$\mathrm{BMI}=$ body mass index $\mathrm{HTN}=$ hypertension, $\mathrm{CAD}=$ coronary artery disease, $\mathrm{CVD}=$ cerebrovascular disease, $\mathrm{PAD}=$ peripheral arterial disease, $\mathrm{ABI}=$ ankle-brachial index, $\mathrm{HDL}=$ high-density lipoprotein; $\mathrm{WBC}=$ white blood cell, $\mathrm{CRP}=\mathrm{C}$-reactive protein, $\mathrm{Lp}$-PLA2= lipoprotein-associated phospholipase A2.

* Top versus bottom tertile 
Table 3

Association of inflammatory markers with all-cause mortality: Cox proportional hazard models

\begin{tabular}{|c|c|c|c|}
\hline & $1^{\text {st }}$ tertile & $2^{\text {nd }}$ tertile & $3^{\text {rd }}$ tertile \\
\hline $\begin{array}{l}\text { WBC count } \\
\left(\times 10^{3} / \mathrm{mm}^{3}\right)\end{array}$ & $<6.3$ & $6.3-7.8$ & $\geq 7.9$ \\
\hline $\begin{array}{l}\text { All patients } \\
\text { Patients with PAD }\end{array}$ & 1 & $\begin{array}{c}1.66 \\
(0.72-3.85) \\
1.66 \\
(0.61-4.53)\end{array}$ & $\begin{array}{c}3.37 \\
(1.56-7.27) \\
4.09 \\
(1.57-10.64)\end{array}$ \\
\hline $\begin{array}{c}\text { CRP } \\
(\mathrm{mg} / \mathrm{L})\end{array}$ & $<2.40$ & $2.40-5.49$ & $\geq 5.50$ \\
\hline $\begin{array}{l}\text { All patients } \\
\text { Patients with PAD }\end{array}$ & 1 & $\begin{array}{c}1.94 \\
(0.91-4.14) \\
1.96 \\
(0.81-4.77)\end{array}$ & $\begin{array}{c}2.12 \\
(0.97-4.62) \\
2.70 \\
(1.11-6.60)\end{array}$ \\
\hline $\begin{array}{l}\text { Lp-PLA2 } \\
\text { (ng/ml) }\end{array}$ & $<275$ & $275-383$ & $\geq 384$ \\
\hline Patients with PAD & $\begin{array}{l}1 \\
1\end{array}$ & $\begin{array}{c}1.62 \\
(0.79-3.29) \\
1.62 \\
(0.73-3.60)\end{array}$ & $\begin{array}{c}1.29 \\
(0.64-2.59) \\
1.35 \\
(0.62-2.91)\end{array}$ \\
\hline
\end{tabular}

Hazard ratio is adjusted for age, sex, smoking, hypertension, $\mathrm{CAD} / \mathrm{CVD}$ history, serum creatinine and $\mathrm{ABI}$; $\mathrm{WBC}=$ white blood cell, $\mathrm{CRP}=\mathrm{C}$-reactive protein, $\mathrm{Lp}$-PLA2 $=$ lipoprotein-associated phospholipase $\mathrm{A} 2, \mathrm{CAD}=$ coronary artery disease, $\mathrm{CVD}=$ cerebrovascular disease, $\mathrm{ABI}=$ ankle-brachial index. $\mathrm{n}=217$. 
Table 4

Integrated Discrimination Improvement (IDI) with WBC count and CRP

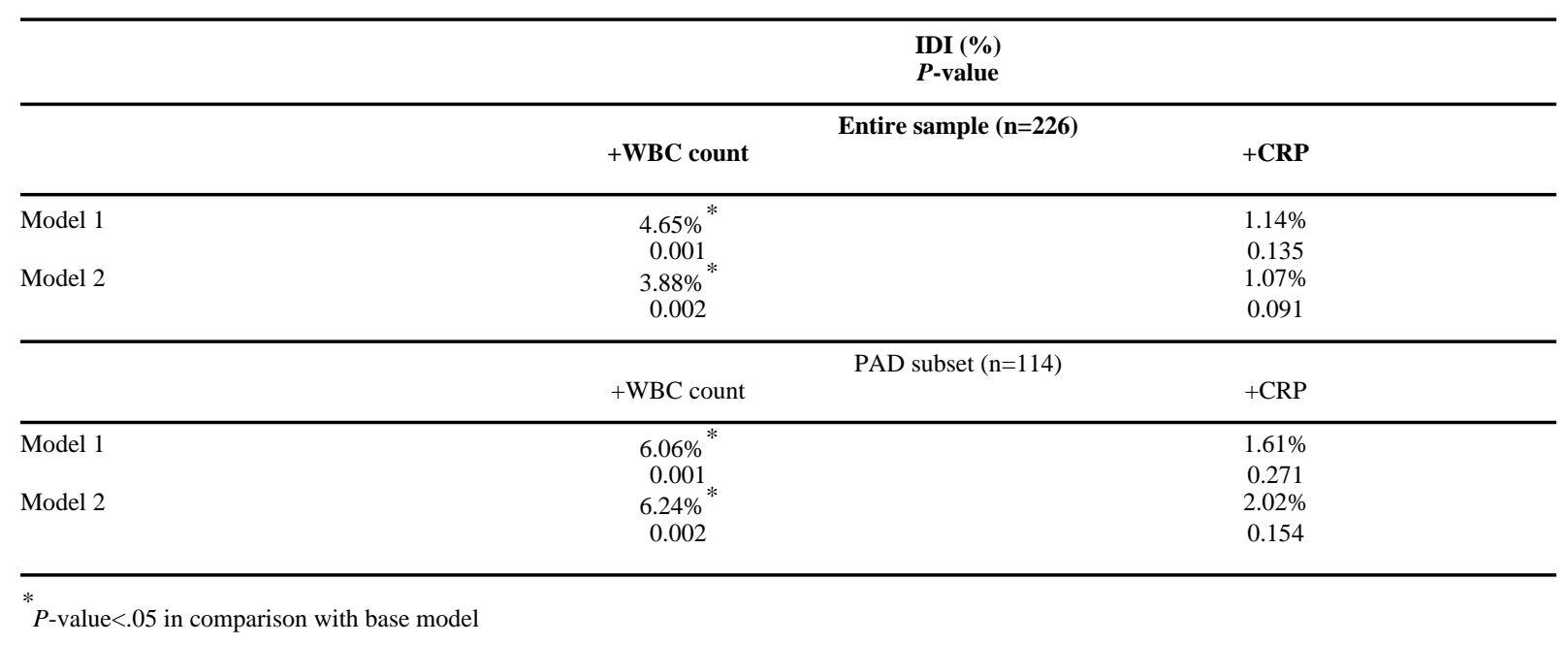

Model 1 includes age and sex; Model 2 includes age, sex, serum creatinine, and ABI (significant predictors of death after performing Cox PH regression with stepwise backward elimination) 